University of Rhode Island

DigitalCommons@URI

The Rhode Island Current Conditions Index

Economics

$10-2005$

\title{
Rhode Island Current Conditions Index - October 2005
}

Leonard Lardaro

University of Rhode Island, lardaro@uri.edu

Follow this and additional works at: https://digitalcommons.uri.edu/ricci

Part of the Econometrics Commons

Terms of Use

All rights reserved under copyright.

\section{Recommended Citation}

Lardaro, Leonard, "Rhode Island Current Conditions Index -- October 2005" (2005). The Rhode Island Current Conditions Index. Paper 98.

https://digitalcommons.uri.edu/ricci/98

This Article is brought to you for free and open access by the Economics at DigitalCommons@URI. It has been accepted for inclusion in The Rhode Island Current Conditions Index by an authorized administrator of DigitalCommons@URI.For more information, please contact digitalcommons-group@uri.edu. 


\section{GURRENT}

BI N

The third quarter's disappointment extended to the beginning of the fourth quarter, as the Current Conditions Index declined from its "first gear" value of 58, which it had remained at for all of last quarter, to its neutral value of 50 in October. While Rhode Island's economy continues to grow, it does so without a great deal of momentum. The story should be familiar by now: the forces generating positive momentum continue to be offset by negative factors. But the greatest disappointment has to be the fact that as the national economy accelerated in Q3 (from 3.3 percent real GDP growth in Q2 to 4.3 percent in Q4), Rhode Island's economy failed to grow faster. October's $\mathrm{CCI}$ value indicates that we might be slipping even more relative to the national economy as 2005 comes to an end.

Fortunately, there was some good news in October. Rhode Island's Labor Force and New Claims turned in strong performances. The bad news was a slowing in labor demand. Retail Sales, which has been one of our strongest indicators for quite a while, rose by 2.5 percent in October. While the October growth in Retail Sales was below its longer-term average, this rate of growth is still quite respectable. October

\begin{tabular}{lr}
\multicolumn{2}{c}{ CCI Indicators - \% Change } \\
Government Employment & -0.5 \\
US Consumer Sentiment & -19.2 \\
Single-Unit Permits & 11.5 Y \\
Retail Sales & $2.5 \mathrm{Y}$ \\
Help Wanted Advertising & -1.0 \\
Priv. Serv-Prod Employment & 2.1 Y \\
Man-Hours Manufacturing & -3.4 \\
Manufacturing Wage & 1.5 Y \\
Labor Force & 2.7 Y \\
Benefit Exhaustions & 13.0 \\
New Claims & -11.2 Y \\
Unemployment Rate & 10.2 \\
\multicolumn{1}{c}{ Y = I mproved Value } &
\end{tabular}

also witnessed another sharp drop in US Consumer Sentiment (19.2 percent). This was the tenth decline in the last year, reflecting the residual effects of higher energy costs.

The demand for labor, in terms of Help Wanted Advertising, fell for the first time since December of 2002. This doesn't come as a total surprise, as this indicator has been weakening since July. One effect of this slowing in labor demand was a worsening of long-term unemployment. Benefit Exhaustions, which reflect long-term unemployment, rose by 13 percent in October, its first increase in the past four months. While this was occurring, layoffs, as measured by New Claims, declined by 11.2 percent, its best performance in well over a year.
October marked the end of a four-month period where both New Claims and Benefit Exhaustions had improved.

October saw yet another dramatic rise in our Labor Force $(+2.7 \%)$, an increase of almost 15,000 over its value last October. Our Labor Force has now risen every month since March, reversing last year's string of persistent declines. In view of such rapid Labor Force growth, the rise in our Unemployment Rate from 4.9 percent last October to 5.4 percent this October, is less of a problem than it appears.

Government Employment fell again in October (by $0.5 \%$ ), remaining below 66,000 . As this was occurring, the rate of growth in Private Service-Producing Employment slowed for the third consecutive month, to 2.1 percent. Fortunately, even though payroll employment now has fallen on a monthto-month basis for three consecutive months, none of these changes has been statistically significant.

While there was weakness in our goods-producing sector, the decline of 3.4 percent in Manufacturing Man-hours was actually an improvement over September. And, even though Manufacturing Wage growth slowed to 1.5 percent in October, this growth rate was the second fastest in the last year. Unfortunately, new home construction, in terms of Single-Unit Permits, rose by $\mathbf{1 1 . 5}$ percent in October, largely the result of a very weak comparison month last year.

Even though Rhode Island began the fourth quarter on a sour note, I do not to expect continual deterioration as this quarter progresses. Since energy prices failed to spike sharply as the colder weather arrived, the performance of the national economy will likely exceed our earlier expectations for the fourth quarter, hopefully boosting Rhode Island's performance.

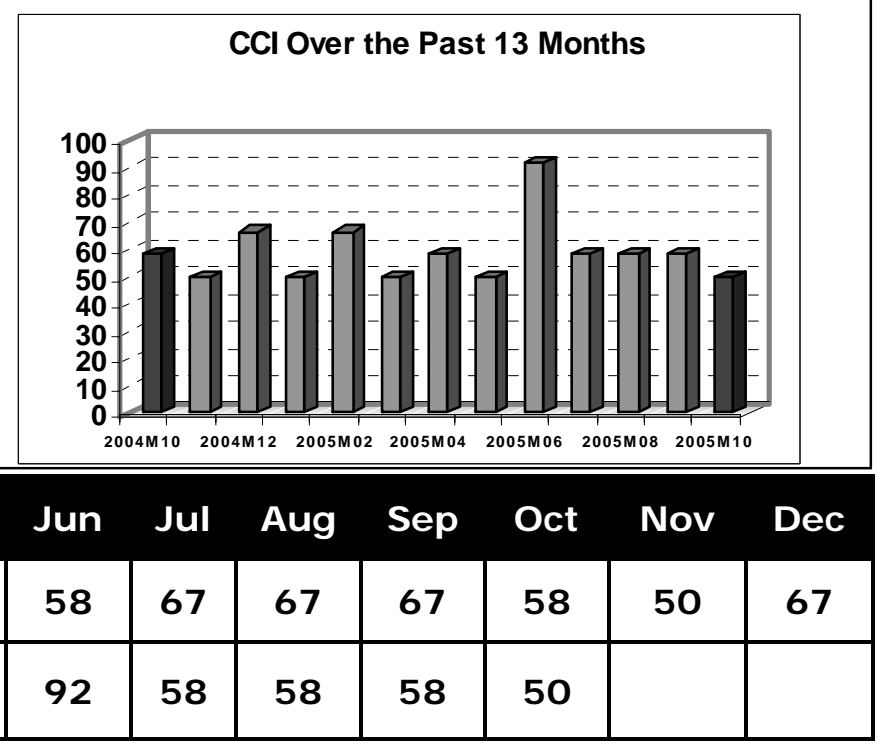

